\title{
Detritus-based patches of high secondary production in the nearshore benthos
}

\author{
Eric W. Vetter \\ Scripps Institution of Oceanography, UCSD 0201, 9500 Gilman Dr., La Jolla, California 92093-0201, USA
}

\begin{abstract}
Topographical features like depressions and submarine canyons accumulate organic debris that fuel patches of intense secondary production. A submarine canyon system off the coast of La Jolla, California, USA, harbors an assemblage of leptostracan and amphipod crustaceans whose local density and secondary production greatly exceed those of any natural system yet reported. These crustaceans utilize large accumulations of macrophyte detritus as both habitat and food, and are preyed on by numerous species of fishes. Bottom topographies acting as detritus traps are relatively common along many coasts and provide an important mechanism to channel marine macrophyte production into higher trophic levels.
\end{abstract}

KEY WORDS: Secondary production-Dense assemblage Leptostracans Submarine canyon Detritus S Saprotrophic

\section{INTRODUCTION}

Topographical features accumulating organic debris are probable sites of natural organic enrichment. Submarine canyons act as sinks for materials moving along the shore at canyon depths and often provide permanent sources of high food density on the continental shelf and slope (Dill 1964, Shepard \& Dill 1966, Griggs et al. 1969, Rowe et al. 1982, Josselyn et al. 1983, McHugh et al. 1992). I studied the potential contribution to the benthos of large quantities of kelp and surfgrass detritus within the La Jolla Bight, which accumulate along the floor of the La Jolla Submarine Canyon in Southern California, USA, forming a persistent mat of organic debris.

A small portion of the canyon's detritus habitat that is shallow enough to study with SCUBA was sampled monthly for 1 yr. The detritus fauna was dominated by leptostracan and amphipod crustaceans whose local density and secondary production exceed all such values found in the literature for natural systems. These abundant crustaceans were consumed by various species of fishes, many of which were ubiquitous over the detritus. If, as seems likely, features which accumulate detritus are relatively common in nearshore regions, they would provide an important but patchy pathway for channeling marine macrophyte production to higher trophic levels through a saprotrophic chain.

The detritus habitat within the La Jolla Submarine Canyon is dominated by amphipod and leptostracan crustaceans, but is also inhabited by a wide variety of animals including crabs, actopuses, juvenile fishes, snails, polychaete worms and isopods. The leptostracans, which include 2 undescribed species of Nebalia, and the most abundant amphipods, Orchomene limodes and Aoroides spinosus, at times achieve a cumulative density of over 3 million individuals $\mathrm{m}^{-2}$, with biomass exceeding $1 \mathrm{~kg}$ (dry wt) $\mathrm{m}^{-2}$.

The genus Nebalia ranges from the Arctic to the Antarctic and from intertidal to lower continental slope depths. The 2 species of Nebalia investigated here are undescribed and inhabit subtidal accumulations of detritus in the La Jolla Canyon, in San Diego Bay, and along the San Diego sewage outfall pipe (Pt. Loma). They have been collected from 5 to $60 \mathrm{~m}$, but may occur much deeper. Length ranges from 1.5 to $17 \mathrm{~mm}$, with an average of $4.5 \mathrm{~mm}$. Nebalia spp. brood their young in an external chamber until they are released as juveniles, with no planktonic dispersal stage.

Orchomene limodes, a lysianassid amphipod, was described from Scripps Canyon (Meador \& Present 1985) and, like Nebalia spp., is a scavenger and detri- 
tivore. The average length of these animals is about $2 \mathrm{~mm}$. Aoroides spinosa, a corophioid amphipod, is the only member of the mat fauna also present in the sand plain surrounding the canyon. It averages about $3.5 \mathrm{~mm}$ in length. Capitella sp., a capitellid polychaete, was occasionally abundant in organically enriched sediments on the periphery of the detritus mat. It builds vertical tubes of agglutinated sand grains and ingests the anoxic sediment at the base of the tube (Fauchald \& Jumars 1979). This species is commonly used as an indicator of disturbed, polluted or organically enriched sediments. Though at times abundant, Capitella sp. was very patchy in space and time. They could recruit and reproduce in less than a month, taking advantage of ephemeral patches of enriched sediments in and around the detritus fields. Their production was likely high relative to that of the surrounding sand community, but still much lower than that of the crustacean populations studied.

\section{MATERIALS AND METHODS}

Study site. The La Jolla submarine canyon system, located off the coast of San Diego $\left(32^{\circ} 52^{\prime} N, 117^{\circ}\right.$

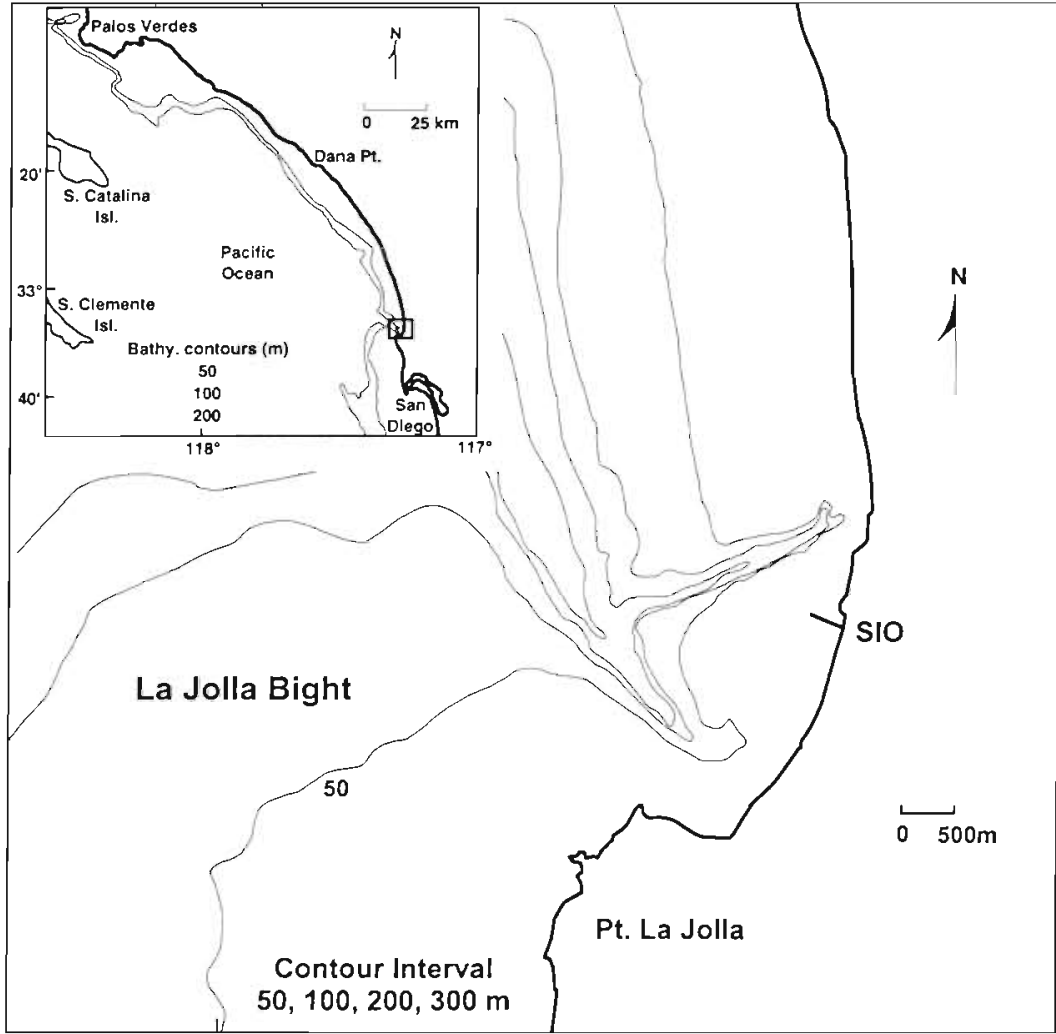

Fig. 1. The coast of Southern California, USA. Area of detail shows the nearshore portion of La Jolla Canyon. Scripps Canyon is seen approaching the coast north of the Scripps Institution of Oceanography (SIO) pier $15^{\prime} \mathrm{W}$ ) is composed of 2 canyons: Scripps Canyon, which originates at a depth of $18 \mathrm{~m}, 150 \mathrm{~m}$ from shore, $900 \mathrm{~m}$ north of the Scripps Institution of Oceanography (SIO) pier, and La Jolla Canyon, which originates at a depth of $22 \mathrm{~m}, 200 \mathrm{~m}$ from shore, and $1200 \mathrm{~m}$ south of the SIO pier (Fig. 1). The 2 canyons merge $1800 \mathrm{~m}$ from shore at a depth of $300 \mathrm{~m}$. Beyond that point, the canyon descends to the northwest to a depth of about $500 \mathrm{~m}$, below which it becomes known as the La Jolla Fan Valley, terminating at the floor of the San Diego Trough at a depth of $1100 \mathrm{~m}$ (Shepard \& Dill 1966).

Surfgrass and algal detritus are present in the canyon year-round. Large accumulations have been observed as shallow as $10 \mathrm{~m}$ and on the deepest submersible dives into the La Jolla Canyon (300 m: Inman et al. 1976; $686 \mathrm{~m}$ : Shepard \& Dill 1966), and the San Diego Trough (1200 mi R. Dill \& R. Vetter pers. comm.). In addition to covering the floor of the canyon, the detritus extends shoreward over the nearshore sand plain where the tributaries of the canyons originate. Most work was conducted on portions of the detritus mat that lie shoreward of Scripps Canyon, because their shallower depth (15 to $28 \mathrm{~m}$ ) afforded both greater safety and diving time. Samples were taken as deep as $60 \mathrm{~m}$ in Scripps Canyon and at various depths in La Jolla Canyon to establish that the same processes studied in the shallow reaches of Scripps Canyon were operating there. Data reported here were collected from March 1992 to March 1993.

Detritus field measurements. One of the larger tributaries of Scripps Canyon, South Branch, was the primary detritus study site. The detritus field that enters South Branch was measured monthly or more frequently if changes in size were observed. A transect line was extended from the origin of South Branch shoreward to the shallow edge of the detritus mat. The width and thickness of the detritus was measured every $3.05 \mathrm{~m}$ along the transect. Ihickness was measured with a pointed, calibrated rod, which was pushed in until resistance from underlying sediment was encountered. Detritus was often present much deeper than recorded, but further down it was mixed or inter-layered with sand and uninhabited by the macrofaunal invertebrates under study. Such measurements revealed the extent of the detritus habitat, not the overall volume of material. Both 
the area and inhabitable volume were calculated in $3.05 \mathrm{~m}$ increments and summed to give the total value.

Quantitative sampling. Both the sediments surrounding the detritus and the detritus habitat itself were quantitatively sampled. The detritus mat was sampled at least monthly, weather permitting. The long, tough strands of surfgrass and kelp made sampling this habitat problematic. Cores were ineffective; even metal corers with sharpened edges cut the material with difficulty and allowed many animals to escape. The only method that took reliable samples used a large steel cylinder $\left(0.185 \mathrm{~m}^{2}\right)$ which was used to isolate a portion of the mat. Hedge trimmers were employed to cut the detritus along the inner wall of the cylinder and then a vacuum lift was used to remove the material in the cylinder. The vacuum lift consisted of an acrylic tube, $182 \mathrm{~cm}$ long, $8 \mathrm{~cm}$ diameter, with a $500 \mu \mathrm{m}$ mesh plankton net attached to the upper end and air injection ports on the lower end. Air was injected from a scuba tank with the tube held vertically so that the rising air would expand and displace water out of the upper end, causing a powerful suction at the lower opening. Vacuuming would often need to be interrupted several times to cut more material with the shears. The weight of the cylinder compressed the underlying detritus, preventing animals from entering or exiting beneath it. When the detritus mat was thick (>80 cm) a complete sample (down to sand) could not be obtained. At such times sampling resulted in a cone-shaped excavation beneath the cylinder, but even then, few animals escaped the vacuum because most were distributed in the upper $20 \mathrm{~cm}$ of the detritus and were captured in the initial suctioning.

From March through September 1992 only 1 sample was taken per sampling date. Thereafter, based on accumulated experience, we were able to collect and process 2 samples per collection date. More replicates would have been desirable; however, the difficulty involved in working with this material made that unfeasible. The lack of additional replicates is somewhat compensated for by the large size of the sampler $\left(0.185 \mathrm{~m}^{2}\right)$ and is made less troublesome by the low temporal and spatial variability of the samples (Vetter 1995). When only 1 sample was taken, its location was selected haphazardly; when 2 were taken, the first was selected haphazardly in a central region of the mat, and the second about $1 \mathrm{~m}$ from the periphery of the mat. There was no trend detected in abundance or biomass from the center to the periphery of the mat (Vetter 1995). The volume of the samples ranged from 20 to 751 of detritus.

The animals were separated from the detritus by flotation in a $76 \mathrm{l}$ tub. About $35 \mathrm{l}$ of water was poured onto a handful of detritus from a height of $1.2 \mathrm{~m}$ so the detritus would be well mixed and bubbles would be produced to carry the macrofaunal crustaceans to the surface where their hydrophobic exoskeletons would trap them in the surface film. The animals were skimmed off, the remaining water was poured through a $500 \mu \mathrm{m}$ sieve and the process was repeated. The first wash used fresh water to shock the amphipods into releasing their hold on the detritus. The second used seawater and brought almost all of the remaining animals to the surface. Additional washes were often performed but they usually collected only a few animals. The process was continued, 1 handful of detritus at a time, until the entire sample had been extracted. This method was not $100 \%$ effective in recovering the mat fauna, but occasional careful inspection of the washed detritus turned up very few missed amphipods and leptostracans. Animals with a high specific gravity or without hydrophobic cuticles such as gastropods, many isopods, crabs, polychaete worms, and others were not well sampled with this method.

A total of 4 to 81 of tightly packed amphipods and leptostracans was collected per sample. Animals were fixed in $4 \%$ formalin in seawater for $48 \mathrm{~h}$ and transferred to $70 \%$ EtOH. A Folsom plankton splitter (Omori \& Ikeda 1984) was used to reduce the sample to a manageable size (between $1 / 256$ and $1 / 1024$ of the original sample). The preserved animals were sorted to species and counted. Carapace length of the leptostracans was measured using a dissecting microscope equipped with an ocular micrometer (magnification: $\times 12, \times 25$ or $\times 50$ ). Biomass of individual Nebalia sp. was calculated by regressing carapace length on dry weight [dry weight $(g)=0.00006$ (carapace length, $\mathrm{mm})^{2.577}, \mathrm{r}^{2}=0.97$ ]. Dry weight of the amphipods was measured on a Sartorius analytical balance after 2 to $3 \mathrm{~d}$ in a drying oven at $52^{\circ} \mathrm{C}$.

Density and production data are given in $\mathrm{m}^{2}$. The animals are concentrated in the upper portion of the mat, rarely being found deeper than $30 \mathrm{~cm}$ into the detritus, so all values in $\mathrm{m}^{-2}$ are equivalent to values per $0.3 \mathrm{~m}^{3}$.

Secondary production. Estimates of secondary production were calculated for the Nebalia sp. using the average cohort method (Hynes \& Coleman 1968, Hamilton 1969, Benke 1979). This involves the calculation of the average cohort, which is simply the average size-frequency distribution of the population based upon samples taken throughout the year. The calculation of production involves quantifying the loss of biomass between successive size intervals. Hamilton's modification of the basic production equation of Hynes \& Coleman (1968) is used here:

$$
P=i \sum_{j=1}^{1}\left(\bar{N}_{j}-\bar{N}_{i+1}\right) \times \sqrt{W_{j} W_{i-1}}
$$


where $P$ is estimated production, $i$ is the number of times the loss occurs (this is equivalent to the number of size classes used, the multiplication accounts for the limited time spent in each size class), $N_{j}$ is the mean number of individuals in size class $j$, and $W$, is the dry weight of individuals belonging to size class $j$. Here $P$ is calculated as the product of: (1) $i$, multiplied by the product of (2) the number of animals lost in step $j$, and (3) the geometric mean of the weight of the animals in step $j$, summed for each time loss occurs (between size classes). The calculation often results in apparent gain (negative loss) of biomass between size increments. This happens whenever there is an increase in average density between size groups (moving down the table). Of course negative loss is not occurring; these values represent an error and must be included in the summation to balance positive error. If a curve is fitted to the histogram of the average cohort, and the equation for that curve is used to regenerate the average cohort, the resulting production table will not include any negative values and the calculated production will closely match that of the original data.

Results obtained were multiplied by $365 / \mathrm{CPI}$ (cohort production interval), to account for multiple broods. The CPI is defined as the time in days from hatching to attainment of largest size class. In the laboratory Nebalia sp. reproduce at $80 \mathrm{~d}$ and attain maximum size by $120 \mathrm{~d}$. Individual female Nebalia sp. from the mat produced as many as 3 broods within an $80 \mathrm{~d}$ period in the lab. Physical disturbance and predation pressure may lower the number of broods a typical female produces in a year, and therefore results are estimated using a range of possible CPIs.

Calculating secondary production for populations in the detritus mat is complicated by the variable size of the habitat within seasons. When the mat shrinks the animals become concentrated in the habitat remaining and when it expands they disperse (Vetter 1995). For this reason the calculations were conducted using both the $\mathrm{m}^{2}$ density and estimates of the population size within the South Branch detritus mat. Those estimates were made by multiplying the density by the mat size at the time of sampling. The value produced using the estimated population size was normalized to the $\mathrm{m}^{2}$ value by dividing the estimate of population secondary production by the average size of the mat.

Amphipod production was calculated by multiplying their average dry weight by a production-to-biomass ratio $(P: B)$ of 4.0 . This value is lower than all the estimates for the leptostracans (see Table 1), but is at the upper end of what is typically reported for benthic amphipods of similar size (2 to 5: Birklund
1977; 3.9: Banse \& Mosher 1980; 1.3 to 3.1: Wildish 1984). Given the abundant resources in this habitat, however, a $P: B$ ratio of 4.0 is probably conservative.

\section{RESULTS}

\section{The detritus mat}

The detritus mat is a dynamic habitat that expands during summer periods of calm and contracts when surge, generated by winter storm waves, moves some or all of the material deeper down into the canyon (Fig. 2). The mat is composed primarily of surfgrass Phyllospadix spp. and kelp (Macrocystis pyrifera Egregia menziesii, Laminaria spp., Pterygophora californica), though other algae including Sargassum spp., Ulva sp., Pelvetia fastigiata and a variety of small red algae are sometimes common. The mat also accumulates animal detritus such as crustacean molts (Emerita analoga and Blepharipoda occidentalis), carrion (cephalopods, fishes, seabirds, pinnipeds), and living animals from the surrounding sand plain. Large numbers of moribund sand dollars Dendraster excentricus, sea pansies Renilla kollikeri, mussels Mytilus californianus and several species of hydroids, bryozoans, sponges and ascidians were frequently seen in the detritus. Material of terrestrial origin such as wood, leaves, golf balls, Frisbees and snorkeling gear were also found in the mat.

Between February 1992 and March 1993, the density of leptostracans plus amphipod crustaceans (hereafter referred to as the mat fauna) varied from $6.40 \times 10^{5}$ to $3.24 \times 10^{6}$ ind. $\mathrm{m}^{-2}$ with a mean of $1.47 \times 10^{6}$ ind. $\mathrm{m}^{-2}$. Mean density of the leptostracans was $6.9 \times 10^{5} \mathrm{~m}^{-2}$ (SD: $4.4 \times 10^{5} ; \mathrm{SD}$ of $2.4 \times 10^{5}$ without the 29 February

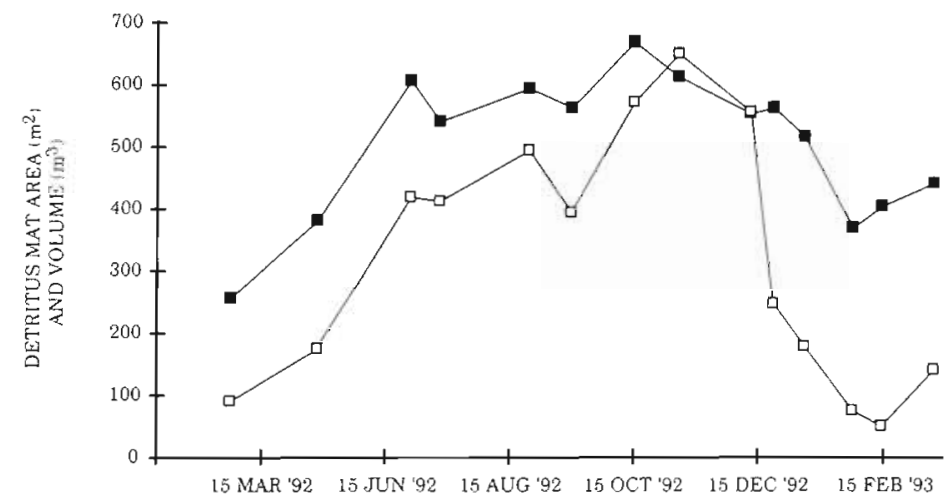

Fig. 2. Area (匹) and volume (0) of the South Branch detritus mat from March 1992 to March 1993. Scale is the same for both measures. Mat length averaged $60 \mathrm{~m}$, width $7.5 \mathrm{~m}$. The South Branch detritus mat is usually isolated from the rest of the La Jolla Canyon detritus habitat and probably represents less than $1 \%$ of the total habitat 


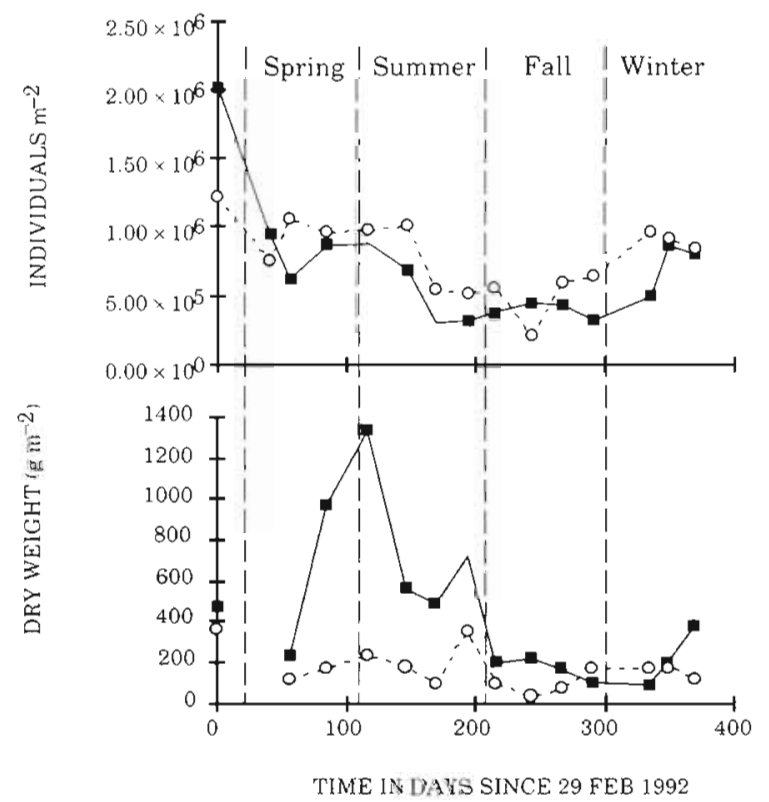

Fig. 3. Density and biomass of leptostracans, Nebalia spp. (ש) and amphipods Orchomene limodes and Aoroides spinosus (O) within the detritus mat

1992 value) and that of the amphipods was $7.8 \times$ $10^{5} \mathrm{~m}^{-2}$ (SD: $2.7 \times 10^{5}$ ). Densities were lowest during the summer and fall (Fig. 3a); however, biomass peaked during the early summer due to the large mean size of the animals at that time (Fig. 3b).

\section{Secondary production of the mat fauna}

The final step in estimating secondary production by the average cohort method is multiplication of the value obtained from the calculation table by the CPI. Laboratory-reared animals had a minimum potential CPI of 3 , but at the canyon, the near elimination of larger size classes following severe physical disturbances should lead to a reduction in the realized CPI. Because of this uncertainty results were determined by using a possible range of CPIs. Tables $1 \& 2$ contain the basic calculation tables for Nebalia secondary production from March 1992 to March 1993 based on mat density (Table 1), and total mat abundance (Table 2). Both tables yield similar results, rounding down to $2400 \mathrm{~g}$ dry wt $\mathrm{m}^{-2} \mathrm{yr}^{-1}$. Table 3 contains the range of production estimates obtained using both calculation methods and CPIs ranging from 1 to 3 .

The mean dry biomass of the amphipod assemblage during the study was $168 \mathrm{~g} \mathrm{~m}^{-2}$. Using a $P: B$ ratio of 4.0, the amphipod annual production is estimated as $672 \mathrm{~g}$ dry wt $\mathrm{m}^{-2} \mathrm{yr}^{-1}$. Amphipod biomass is based on samples that had been preserved in ethanol. Subse- quent analysis has shown that these animals typically lose about $50 \%$ of their dry mass when stored this way, biasing their production estimate downward.

\section{DISCUSSION}

Traditionally the seafloor has been thought to receive organic matter as a slow 'rain of detritus' (Agassiz 1888), composed primarily of fecal pellets, crustacean molts and other fine particulate material (Rowe \& Staresinic 1979). The recent discovery of large quantities of phytodetritus on the deep sea floor (Lampitt 1985, Thiel et al. 1988/1989) has called into question long-held views on the rate of delivery of food to the benthos and its degree of food limitation. Such material may contribute relatively little to sediments on narrow continental shelves however, because high current velocities reduce deposition, and much of the fine suspended matter incorporated in the sediments first passes through the guts of suspension-feeding animals, which lower its organic content. The frequency and importance of large food falls, such as macrophytes (wood, algae, seagrass) fish, seabird and marine mammal carcasses to the deep-sea and nearshore benthos has also received recent attention (Stockton \& DeLaca 1982, Smith 1985, Grassle \& MorsePorteous 1987, Priede et al. 1991). Phytodetritus and carcasses provide a rich resource which is patchy in space and time; because of their more refractory nature, macrophyte falls result in longer lasting, if lower intensity enrichments where they come to rest. The large size and persistence of the enriched area described here results from benthic topography which traps and retains the locally abundant bedload detritus. Most of the more permanent food patches studied are anthropogenic enrichments such as those associated with municipal and industrial sewage outfalls (Pearson \& Rosenberg 1978), fish farming (Ritz et al. 1989), or oil contamination (Suchanek 1993).

The amphipod and leptostracan densities measured here are an order of magnitude greater than any natural macrofaunal assemblage previously reported in the literature (Vetter 1994). The maximum density for both taxa occurred on 29 February 1992 when the leptostracan density was estimated as $2.02 \times 10^{6} \mathrm{~m}^{-2}$ and amphipod density as $1.22 \times 10^{6} \mathrm{~m}^{-2}$. Studies on substrates other than detrital mats have rarely reported macrofaunal densities that exceed $10^{5} \mathrm{~m}^{-2}$. The sand plain surrounding this habitat has much lower macrofaunal densities, ranging from $4.0 \times 10^{3}$ to $2.0 \times 10^{4}$ $\mathrm{m}^{-2}$, with a mean of $9.0 \times 10^{3} \mathrm{~m}^{-2}$. Of the 4 abundant crustaceans in the detritus, only Aoroides spinosus lives in the surrounding sediments where it may achieve densities of 200 to $300 \mathrm{~m}^{-2}$. Another un- 
Table 1. Nebalia sp. Calculation of standing biomass and secondary production (g dry wt $\mathrm{m}^{-2} \mathrm{yr}^{-1}$ ) using the average cohort method (Eq. 1). Data based on density in the South Branch detritus mat. Size class: carapace length; $\bar{N}$ : average number of individuals of class $j_{i} \bar{N}_{j}-\bar{N}_{j}+1$ number of individuals lost from one size class to the next. Wj: mean dry weight of individuals belonging to size class $j_{i} \bar{N}_{j} \bar{W}_{j}$ : biomass (dry) of size class $j_{i} W_{\text {gm }}$ : geometric mean of mean dry weight of 2 successive size classes; Biomass lost $=\left(N_{j}-N_{j+1}\right) \times W_{\text {gmi }} P_{j}$ production $=$ Biomass lost $\times$ number of times loss occurred

\begin{tabular}{|c|c|c|c|c|c|c|c|}
\hline $\begin{array}{l}\text { Size class } \\
\text { (mm) }\end{array}$ & $\begin{array}{l}\bar{N} \\
\text { (ind. } \mathrm{m}^{-2} \text { ) }\end{array}$ & $\begin{array}{l}\bar{N}_{i}-\bar{N}_{i+1} \\
\text { (ind. } m^{-2} \text { ) }\end{array}$ & $\begin{array}{l}W_{j} \\
(g)\end{array}$ & 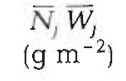 & $\begin{array}{l}W_{g m} \\
(g)\end{array}$ & $\begin{array}{l}\text { Biomass lost } \\
\left(\mathrm{g} \mathrm{m}^{-2}\right)\end{array}$ & $\begin{array}{c}P_{j} \\
\left(g m^{-2}\right)\end{array}$ \\
\hline 0.8 & 134858 & - & 0.00003 & 4.553 & - & - & - \\
\hline 1 & 119889 & 14969 & 0.00006 & 7.193 & 0.00005 & 0.674 & 21 \\
\hline 1.2 & 72080 & 47809 & 0.00010 & 6.919 & 0.00008 & 3.628 & 112 \\
\hline 1.4 & 81614 & -9534 & 0.00014 & 11.654 & 0.00012 & -1.116 & -35 \\
\hline 1.6 & 78610 & 3005 & 0.00020 & 15.836 & 0.00017 & 0.510 & 16 \\
\hline 18 & 56872 & 21737 & 0.00027 & 15.520 & 0.00023 & 5.097 & 158 \\
\hline 2 & 42546 & 14327 & 0.00036 & 15.232 & 0.00031 & 4.478 & 139 \\
\hline 2.2 & 27895 & 14651 & 0.00046 & 12.767 & 0.00040 & 5.931 & 184 \\
\hline 2.4 & 24030 & 3866 & 0.00057 & 13.763 & 0.00051 & 1.979 & 61 \\
\hline 2.6 & 19985 & 4044 & 0.00070 & 14.069 & 0.00063 & 2.568 & 80 \\
\hline 2.8 & 20779 & -794 & 0.00085 & 17.705 & 0.00077 & -0.615 & -19 \\
\hline 3 & 17441 & 3338 & 0.00102 & 17.753 & 0.00093 & 3.109 & 96 \\
\hline 3.2 & 17354 & 87 & 0.00120 & 20.861 & 0.00111 & 0.096 & 3 \\
\hline 3.4 & 16501 & 854 & 0.00141 & 23.189 & 0.00130 & 1.109 & 34 \\
\hline 3.6 & 11172 & 5329 & 0.00163 & 18.191 & 0.00151 & 8.061 & 250 \\
\hline 3.8 & 9189 & 1983 & 0.00187 & 17.200 & 0.00175 & 3.461 & 107 \\
\hline 4 & 10470 & -1281 & 0.00214 & 22.367 & 0.00200 & -2.561 & -79 \\
\hline 4.2 & 3832 & 6638 & 0.00242 & 9.284 & 0.00227 & 15.100 & 468 \\
\hline 4.4 & 4288 & -456 & 0.00273 & 11.711 & 0.00257 & -1.173 & -36 \\
\hline 4.6 & 3199 & 1090 & 0.00306 & 9.796 & 0.00289 & 3.151 & 98 \\
\hline 4.8 & 1254 & 1945 & 0.00342 & 4.285 & 0.00324 & 6.292 & 195 \\
\hline 5 & 3753 & -2499 & 0.00380 & 14.247 & 0.00360 & -9.000 & -279 \\
\hline 5.2 & 2219 & 1533 & 0.00420 & 9.322 & 0.00399 & 6.123 & 190 \\
\hline 5.4 & 2228 & -9 & 0.00463 & 10.314 & 0.00441 & -0.037 & -1 \\
\hline 5.6 & 2117 & 111 & 0.00508 & 10.764 & 0.00485 & 0.537 & 17 \\
\hline 5.8 & 2778 & -660 & 0.00557 & 15.458 & 0.00532 & -3.513 & -109 \\
\hline 6 & 4014 & -1236 & 0.00607 & 24.378 & 0.00581 & -7.188 & -223 \\
\hline 6.2 & 3629 & 385 & 0.00661 & 23.983 & 0.00634 & 2.439 & 76 \\
\hline 6.4 & 4742 & -1113 & 0.00717 & 34.009 & 0.00689 & -7.662 & -238 \\
\hline 6.6 & 1553 & 3188 & 0.00776 & 12.061 & 0.00746 & 23.793 & 738 \\
\hline 6.8 & 912 & 641 & 0.00839 & 7.651 & 0.00807 & 5.172 & 160 \\
\hline 7 & 0 & 912 & - & - & 0.00839 & 7.655 & 237 \\
\hline Total: & 801802 & & & 452 & & & 2421 \\
\hline
\end{tabular}

described species of Nebalia inhabits the surrounding sediments at densities as high as $1.0 \times 10^{3} \mathrm{~m}^{-2}$. Few previous studies have reported macrofaunal densities above $1.0 \times 10^{5} \mathrm{~m}^{-2}$; the highest found was $7.5 \times$ $10^{5} \mathrm{~m}^{-2}$, for capitellid polychaetes (Mediomastus ambiseta) inhabiting sediments contaminated by oil (Grassle \& Grassle 1974). No other reports of densities exceeding $2.5 \times 10^{5} \mathrm{~m}^{-2}$ were found.

The great densities achieved by the detritus-mat fauna may partially result from the relatively large 3dimensional extent of their habitat. The surface portion of the mat is composed of unconsolidated macrophyte detritus typically overlying a layer of mixed sand and detritus that is usually devoid of macrofauna. The detritus layer itself is often more than $1 \mathrm{~m}$ thick. However, oxygen levels fall off rapidly, being 3 - to 4 -fold lower $20 \mathrm{~cm}$ into the detritus mat than at the mat surface (Vetter 1995) and the animals are typically distributed only within the top 20 to $30 \mathrm{~cm}$. The highest density of these animals found in enriched sediments surrounding the detrital accumulations was $6.2 \times$ $10^{5} \mathrm{~m}^{-2}$ (all juvenile leptostracans and amphipods). Capitella sp., frequently abundant in a halo of enriched sediments around the mat, had a maximum density of $1.01 \times 10^{5} \mathrm{~m}^{-2}$.

Secondary production of the leptostracans is estimated at between 2400 and $7200 \mathrm{~g}$ dry wt $\mathrm{m}^{-2} \mathrm{yr}^{-1}$. The estimated $P: B$ ratio was between 5.2 and 15.7. Because these animals are capable of producing at least 3 broods in the lab, and grow larger in nature than in the most favorable lab conditions, I consider a CPI of 1.5 to be the lowest plausible value for this population and will use it for comparative purposes. A CPI of 1.5 yields a $P: B$ of 7.86 , the only other reported 
Table 2. Nebalia sp. Calculation of standing biomass and secondary production ( $\mathrm{g}$ dry $\mathrm{wt} \mathrm{m}^{-2} \mathrm{yr}^{-1}$ ) using the average cohort method (Eq. 1). Data adjusted for estimated population size in the South Branch detritus mat. Size class: carapace length; $\bar{N} ;$ average number of individuals of class $j_{i} \bar{N}_{j}-\bar{N}_{j+1}$ : number of individuals lost from one size class to the next. $W_{j}$ : mean dry weight of individuals belonging to size class $j_{i} \bar{N} \bar{W}_{i}$ biomass (dry) of size class $j_{i} W_{\text {qm }}$ : geometric mean of mean dry weight of 2 successive size classes; Biomass lost $=\left(N_{j}-N_{1+1}\right) \times W_{\mathrm{gm}} ; P_{j}$ : production $=$ Biornass lost $\times$ number of times loss occurred

\begin{tabular}{|c|c|c|c|c|c|c|c|}
\hline $\begin{array}{l}\text { Size class } \\
(\mathrm{mm})\end{array}$ & $\bar{N}$ & $\bar{N}_{j}-\bar{N}_{i+1}$ & $\begin{array}{r}W \\
(g)\end{array}$ & $\begin{array}{c}\bar{N}_{j} \bar{W}_{j} \\
(\mathrm{~g})\end{array}$ & $\begin{array}{c}W_{g m} \\
(g)\end{array}$ & $\begin{array}{c}\text { Biomass lost } \\
\text { (g) }\end{array}$ & $\begin{array}{c}P_{j} \\
(g)\end{array}$ \\
\hline 0.8 & 49320680 & - & 0.00003 & 1665 & - & - & - \\
\hline 1 & 43612439 & 5708241 & 0.00006 & 2617 & 0.00005 & 257 & 7964 \\
\hline 1.2 & 34882207 & 8730232 & 0.00010 & 3348 & 0.00008 & 663 & 20538 \\
\hline 1.4 & 38944985 & -4062778 & 0.00014 & 5561 & 0.00012 & -476 & -14745 \\
\hline 1.6 & 36805294 & 2139691 & 0.00020 & 7414 & 0.00017 & 363 & 11250 \\
\hline 1.8 & 26871844 & 9933451 & 0.00027 & 7333 & 0.00023 & 2329 & 72201 \\
\hline 2 & 21654520 & 5217324 & 0.00036 & 7753 & 0.00031 & 1631 & 50554 \\
\hline 2.2 & 14763899 & 6890621 & 0.00046 & 6757 & 0.00040 & 2789 & 86469 \\
\hline 2.4 & 12265386 & 2498514 & 0.00057 & 7025 & 0.00051 & 1279 & 39656 \\
\hline 2.6 & 10127502 & 2137884 & 0.00070 & 7129 & 0.00063 & 1357 & 42082 \\
\hline 2.8 & 10587119 & -459618 & 0.00085 & 9021 & 0.00077 & -356 & -11035 \\
\hline 3 & 9324941 & 1262178 & 0.00102 & 9492 & 0.00093 & 1175 & 36439 \\
\hline 3.2 & 9434772 & -109830 & 0.00120 & 11341 & 0.00111 & -121 & -3766 \\
\hline 3.4 & 8292767 & 1142004 & 0.00141 & 11654 & 0.00130 & 1484 & 46013 \\
\hline 3.6 & 5880381 & 2412386 & 0.00163 & 9575 & 0.00151 & 3649 & 113127 \\
\hline 3.8 & 5014785 & 865596 & 0.00187 & 9387 & 0.00175 & 1511 & 46846 \\
\hline 4 & 5623923 & -609138 & 0.00214 & 12014 & 0.00200 & -1218 & -37760 \\
\hline 42 & 2033659 & 3590264 & 0.00242 & 4927 & 0.00227 & 8167 & 253192 \\
\hline 4.4 & 2363666 & -330007 & 0.00273 & 6455 & 0.00257 & -849 & -26314 \\
\hline 4.6 & 1587018 & 776648 & 0.00306 & 4860 & 0.00289 & 2246 & 69629 \\
\hline 4.8 & 728952 & 858067 & 0.00342 & 2491 & 0.00324 & 2776 & 86055 \\
\hline 5 & 1896504 & -1167552 & 0.00380 & 7200 & 0.00360 & -4206 & -130374 \\
\hline 5.2 & 1189494 & 707010 & 0.00420 & 4996 & 0.00399 & 2823 & 87525 \\
\hline 5.4 & 1114492 & 75002 & 0.00463 & 5159 & 0.00441 & 331 & 10253 \\
\hline 5.6 & 1016890 & 97602 & 0.00508 & 5170 & 0.00485 & 474 & 14679 \\
\hline 5.8 & 1293483 & -276593 & 0.00557 & 7199 & 0.00532 & -1471 & -45611 \\
\hline 6 & 1599667 & -306184 & 0.00607 & 9716 & 0.00581 & -1780 & -55185 \\
\hline 6.2 & 1558701 & 40966 & 0.00661 & 10302 & 0.00634 & 260 & 8046 \\
\hline 6.4 & 2176641 & -617940 & 0.00717 & 15612 & 0.00689 & -4255 & -131892 \\
\hline 6.6 & 840366 & 1336275 & 0.00776 & 6525 & 0.00746 & 9972 & 309139 \\
\hline 6.8 & 407984 & 432383 & 0.00839 & 3421 & 0.00807 & 3489 & 108156 \\
\hline 7 & 0 & 407984 & - & - & 0.00839 & 3423 & 106112 \\
\hline Total mat: & 363214960 & & & 223121 & & & 1169243 \\
\hline$m^{-2}$ & 747356 & & & 459 & & & 2406 \\
\hline
\end{tabular}

leptostracan $P: B$ ratio is 22.5 (Rainer \& Unsworth 1991). Because the food source of the animals and their habitat are one and the same, these animals are unlikely to be resource limited and a high $P: B$ ratio is not surprising. The minimum annual production of amphipods was calculated to be $672 \mathrm{~g}$ dry $\mathrm{wt} \mathrm{m}^{-2} \mathrm{yr}^{-1}$, a value that should be considered a minimum estimate for 2 reasons: (1) the $P: B$ ratio involved (4.0) is likely to be an underestimate because of the abundance of food, and was deliberately chosen to be conservative; and (2) the storage of amphipods in alcohol prior to drying and weighing caused them to lose a considerable amount of their biomass into solution. For the
Table 3. Secondary production $\left(\mathrm{g} \mathrm{m}^{-2} \mathrm{yr}^{-1}\right)$ and productionto-biomass ratios of the Nebalia sp., from March 1992 to March 1993. from calculation tables based on either estimated population size or measured density, and a range of possible cohort production intervals (CPI)

\begin{tabular}{|c|c|c|c|c|}
\hline \multirow[t]{2}{*}{ CPI } & \multicolumn{2}{|c|}{ Population } & \multicolumn{2}{|c|}{ Density } \\
\hline & $P$ & $P: B$ & $P$ & $P: B$ \\
\hline 1 & 2406 & 5.24 & 2421 & 5.27 \\
\hline 1.5 & 3609 & 7.86 & 3632 & 7.91 \\
\hline 2 & 4812 & 10.48 & 4842 & 10.55 \\
\hline 2.5 & 6015 & 13.10 & 6053 & 13.19 \\
\hline 3 & 7218 & 15.73 & 7263 & 15.82 \\
\hline
\end{tabular}




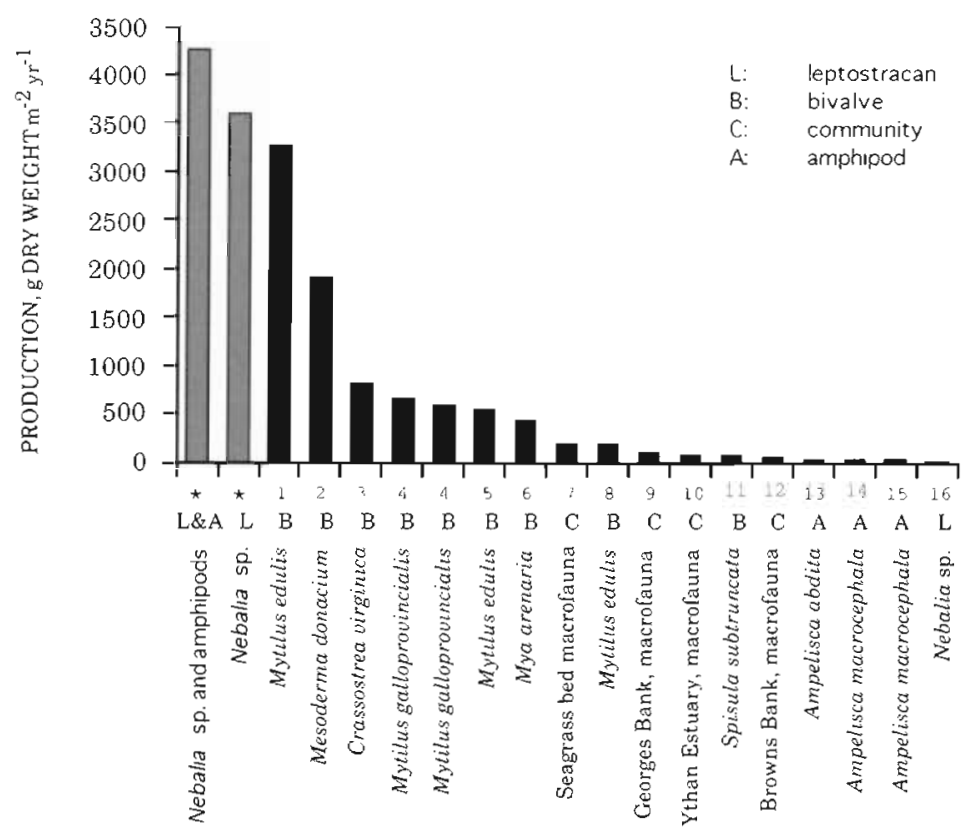

Fig. 4. Secondary production (shell-free dry weight for bivalves) of the detritus mat fauna compared with reports of high secondary production, and highest reports of amphipod and leptostracan production from the literature (numbers indicate citation listed in Table $4_{i} \cdot$ data from this study). The first column combines leptostracan and amphipod production, the second shows only leptostracan production

purposes of this study it matters little whether their secondary production is 500 or $1500 \mathrm{~g}^{\text {dry }} \mathrm{wt} \mathrm{m}^{-2} \mathrm{yr}^{-1}$ i in either case it is an enormous value.

I have found only 2 reports of secondary production in the literature with values even approaching those estimated in the present study (Fig. 4, Table 4). These were production by a Mytilus edulis bed composed of 0,1 , and 2 year class mussels, all of which recruited in great number (3260 g shell-free dry wt m-2 $\mathrm{yr}^{-1}$; Dare 1976), and by another intertidal bivalve, Mesoderma donacium (1996 g shell-free dry wt $\mathrm{m}^{-2} \mathrm{yr}^{-1}$; Arntz et al. 1987). The next 3 highest production reports are from an oyster bed and from mature Mytilus spp. beds, and are at least 4 -fold lower. The highest secondary production found for an amphipod is 2 orders of magnitude lower (Franz \& Tanacredi 1992) than the values reported here.

Detritus mats are probably common in other areas. They have been reported from the Monterey Canyon (Central California) with infaunal densities as high as $5.0 \times 10^{5}$ (Okey 1993). A sample collected by the City of San Diego ocean monitoring program $30 \mathrm{~m}$ to the south at a depth of $65 \mathrm{~m}$ contained the same species of Nebalia found at the La Jolla Canyon, and detritus was recovered with the sample. Surveys in San Diego Bay have turned up leptostracan densities as high as $10000 \mathrm{~m}^{-2}$ in small (1 to $2 \mathrm{~m}^{2}$ ) detritus patches throughout the bay. Other regions accumulating large detrital mats surely exist along the west coast of North America, since all that seems to be required is a source of detritus, a topographic sink, and a favorable current regime. Shepard \& Dill (1966) reported detritus mats in several California canyons, and others are likely to be present in most West Coast canyons. The lack of extensive documentation more likely reflects under-reporting than nonexistence.

Until very recently there have been few published references to localized patches of organic material in the subtidal ocean. Rowe $\&$ Staresinic (1979) reported that in over 200 otter trawls, 50 dives by the submersible ALVIN, and more than 50000 photographs of the deep sea floor, no evidence of large carcasses had ever been observed. However, Smith $(1985,1987)$ found several fish carcasses and 1 whale carcass, and estimated that nekton falls accounted for about $11 \%$ of the benthic community respiration in the Santa Catalina Basin (Southern California Bight). There have been numerous recent reports of seagrasses, macroalgae, and other plant debris in the deep sea (Menzies et al. 1967, Wolff 1976, George \& Higgins 1979, Rowe \& Staresinic 1979, Josselyn et al. 1983, Suchanek et al. 1985, Bach et al. 1986, Alongi 1990), although I have found no reports of regions with a persistent cover of such material. This may be attributable in part to diffi-

Table 4. Citations and taxa for data used in Fig. 4

\begin{tabular}{|rlll|}
\hline 1 & Mussel & Mytilus edulis & Dare (1976) \\
2 & Clam & Mesoderma donacium & Arntz et al. (1987) \\
3 & Oyster & Crassostrea virginica & Dame (1976) \\
4 & Mussel & Mytilus galloprovincialis & Ceccherelli \& Rossi (1984) \\
5 & Mussel & Mytilus edulis & Asmus (1987) \\
6 & Clam & Mya arenaria & Möller \& Rosenberg (1983) \\
7 & Community & Seagrass bed macrofauna & Fredette et al. (1990) \\
8 & Mussel & Mytilus edulis & Craeymeersch et al. (1986) \\
9 & Community & Georges Bank, macrotauna & Steimle (1987) \\
10 & Community & Ythan Estuary, macrofauna & Baird \& Milne (1981) \\
11 & Clam & Spisula subtruncata & Ambrogi \& Ambrogi (1987) \\
12 & Community & Browns Bank, macrofauna & Wildish et al. (1989) \\
13 & Amphipod & Ampelisca abdita & Franz \& Tanacredi (1992) \\
14 & Amphipod & Ampelisca macrocephala & Highsmith \& Coyle (1990) \\
15 & Amphipod & Ampelisca macrocephala & Highsmith \& Coyle (1991) \\
16 & Leptostracan & Nebalia sp. & Unsworth (1987) \\
& & & \\
\hline
\end{tabular}


culties associated with making repeated visits to sites on the deep sea floor.

The 2 Nebalia spp. and Orchomene limodes of the detrital mat are known only from this habitat, but presumably are found where similar conditions exist along the North American west coast. The success of the mat fauna may be due to a suite of several common natural-history traits. All the animals are scavengers, capable of feeding on algal and seagrass detritus and carrion. The leptostracans can grow and reproduce in the laboratory with only organically rich sediments. Nebalia spp, are capable of surviving at very low oxygen tension, although the amphipods are somewhat less tolerant and tend to be found closer to the surface of the mat. All reproduce throughout the year, and at least the Nebalia sp. are iteroparous, capable of producing 2 broods in a 3 mo period. Finally, all of these animals release juveniles ready to exploit the adult habitat, so few, if any, young are exported from the population. It is possible for portions of the habitat to be eliminated by physical disturbance, such as sediment slumps which could bury large portions of the habitat, or storms that could wash it away, exposing uninhabited sediments or rock. Once the detritus builds up again such areas are quickly recolonized by the residual mat fauna from patches that survive disturbances in this topographically complex system.

How important are such localized food hot-spots to fish populations in general? At first glance they seem a modest contribution in relation to the general shelf habitat, but the oceanographic literature suggests that hot-spots may be of crucial importance to some species. In the pelagic realm the importance of food patches to the growth and survival of fishes has long been recognized (Lasker 1975). A long-standing problem has been the apparent insufficiency of the average concentrations of prey to sustain predators (Mullin 1993). On a scale of hundreds of kilometers, Hakanson (1987) found that the nutritional state of zooplankton could be predicted by mesoscale phytoplankton concentration; however, on a population scale it has often been found that over $50 \%$ of zooplankton apparently do not have enough prey immediately available to sustain growth (Mullin \& Brooks 1976, Cox et al. 1983). The problem has been that plankton nets yield an average standing stock of potential prey over an area larger than the scale of dense food patches. As a result, even if the sampling net goes through a food-rich patch, measured concentrations are typically much lower than needed to sustain predators. Many of the pelagic fishes and zooplankton that survive and reproduce have somehow been able to locate and exploit food-rich patches. The same may well be true for some benthic and demersal fishes.
Submarine canyons can facilitate the formation of high-density food patches of vertically migrating animals. Using a dual-beam bioacoustic technique, Greene et. al (1988) found high density demersal layers of krill in submarine canyons off Georges Bank, NW Atlatnic. These layers may result from a funneling effect that concentrates the krill into the canyons as they migrate down during the day. However it comes about, those canyons host a highly concentrated food source on a daily basis. Greene et al. (1988) suggest that squid and demersal fish stocks on Georges Bank are subsidized by exploiting this resource. This is an example of submarine canyons temporarily accumulating food-rich patches through the behavior of the potential prey. In the La Jolla Canyon, food for benthic detritivores is accumulated (and persists) in the canyon through physical processes. The end result is the same, greater production of predators than would be possible in the absence of the rich supply of prey.

The fishes exploiting the detritus-dwelling crustaceans in the La Jolla Canyon include not only species that are resident in the canyon (Oxyjulis californica, Chromis punctipinnis, Scorpaena guttata, Semicossyphus pulcher, Chilera taylori, Paralabrax clathratus). but also others which are frequent visitors (Anisotremis davidsonii, Damalichthys vacra, Embiotoca jacksoni, Phanerodon furcatus). All of the above species are known to prey heavily on the mat fauna (Vetter 1995), and several other species are suspected of doing so. Many of these fish do not typically take small benthic invertebrates (Quast 1971, Allen 1982). However, the high abundance of macrofaunal crustaceans may have led all of these fish to become benthic browsers in this habitat.

The areal extent of the detritus habitat within the La Jolla Canyon system is unknown but probably exceeds 10 ha. The huge secondary production here is made more significant by the taxa that are responsible for it. These macrofaunal crustaceans are easily taken by fishes and thus provide a direct conduit for marine macrophyte production into higher trophic levels. The mat habitat greatly fuels production of local fishes and presumably can subsidize nomadic or long-ranging fishes. Hot-spots of benthic secondary production are likely to be common, but few may be as 'hot' as the habitat described here. Any patch of the seafloor that receives a greater supply of food than its surroundings is hot in the sense that it should have higher than background production. In the calm conditions of the deep sea, such patches can occur on very small scales such as in and around mounds, pits and other biogenic structures in the sediment (Rice \& Lambshead 1994). Grassle \& Grassle (1994, and references therein) assert that such small-scale spatial and temporal variability in food supply is an important factor in maintaining the 
high diversity found in the deep-sea benthos. This patchiness of resources leads to patchy production by species that might not be present if the deep ocean floor were homogeneous with regard to structure and available food (Snelgrove et al. 1992). Hydrothermal vents support the most dramatic examples of benthic hyperproductivity. Lutz et. al (1994) report that vestimentiferan worms at a hydrothermal vent on the East Pacific Rise attained tube length of $85 \mathrm{~cm}$ within $1 \mathrm{yr}$. These worms occur in highly discrete patches of densely packed individuals and their annual production in some instances may well exceed the values reported here.

The general importance of patchiness in natural systems involving everything from disturbance to recruitment to resources is becoming increasingly apparent. Physical features that result in localized enhanced production from ray-pits (VanBlaricom 1982) to seamounts (Rogers 1994) are common. These and other patches of benthic hyperproductivity are important ecologically and could well enhance commercial and sport fisheries over very wide areas.

Acknowledgements. I am grateful to L. V. Basch, R. S. Burton, P. K. Dayton, J. T Enright, R. R. Hessler, N. D. Holland, L. A Levin, D. L. Strong, M. J. Tegner and 3 anonymous reviewers for their critical comments on various versions of this manuscript. For help with the design and fabrication of underwater equipment I thank R. R. McConnaughey. I am especially grateful to divers P. L. Bruggeman, M. D. Stokes, R. J Van Syoc and many others who made this work possible. This research was supported in part by the PADI Foundation, the Sierra Club, Northern San Diego Chapter, and the L. A. Chapter of the Achievement Rewards for College Scientists Foundation. This paper is part of a dissertation submitted for a Ph.D. in Oceanography at Scripps Institution of Oceanography, University of California, San Diego

\section{LITERATURE CITED}

Agassiz, A. (1888). Three cruises of the United States Coast and Geodetic Survey Steamer Blake. Sampson Low, Marston, Searle and Rivington, Ltd, London

Allen, M. J. (1982). Functional structure of soft-bottom fish communities of the Southern California Shelf. Ph.D. thesis, University of California, San Diego

Alongi, D. M. (1990). Bacterial growth rates, production and estimates of detrital carbon utilization in deep-sea sediments of the Solomon and Coral Seas. Deep Sea Res. 37 : $731-746$

Ambrogi, R., Ambrogi, A. O. (1987). Temporal variations of secondary production in the marine bivalve Spisula subtruncata off the Po river delta (Italy). Estuar. coast. Shelf Sci. 25: 369-379

Arntz, W. E., Brey, T. Tarazona, J., Robles, A. (1987). Changes in the structure of a shallow sandy-beach community in Peru during an El Niño event. S. Afr. J. mar. Sci. 5: $645-658$

Asmus, H. (1987). Secondary production of an intertidal mussel bed community related to its storage and turnover compartments. Mar. Ecol. Prog. Ser. 39: 251-266

Bach, S. D., Thayer, G. W., LaCroix, M. W. (1986). Export of detritus from eelgrass (Zostera marina) beds near Beaufort, North Carolina, USA. Mar. Ecol. Prog. Ser. 28: 265-278

Baird, D., Milne, H. (1981). Energy flow in the Ythan Estuary, Aberdeenshire, Scotland. Estuar. coast. Shelf Sci. 13: $455-472$

Banse, K., Mosher, S. (1980). Adult body mass and annual production/biomass relationships of field populations. Ecol. Monogr. 50: 355-379

Benke, A. C. (1979). A modification of the Hynes method for estimating secondary production with particular significance for multivoltine populations. Limnol. Oceanogr. 24: $171-176$

Birklund, J. (1977). Biomass growth and production of the amphipod Corophium insidiosum Crawford and preliminary notes on Corophium volutator (Pallas). Ophelia 16: $187-203$

Ceccherelli, V. U., Rossi, R. (1984). Settlement, growth and production of the mussel Mytilus galloprovincialis. Mar. Ecol. Prog. Ser. 16: 173-184

Cox, J. L., Willason, S., Harding, L. (1983). Consequences of distributional heterogeneity of Calanus pacificus grazing. Bull. mar. Sci. 33: 213-236

Craeymeersch, J. A., Herman, P. M. J., Meire, P. M. (1986). Secondary production of an intertidal mussel (Mytilus edulis L.) population in the Eastern Scheldt (S. W. Netherlands). Hydrobiologia 133: 107-115

Dame, R. F. (1976). Energy flow in an intertidal oyster population. Estuar. coast. Shelf Sci. 4: 243-253

Dare, P. J. (1976). Settlement, growth and production of the mussel, Mytilus edulis L., in Morecambe Bay, England. Fish. Invest., Lond. II 28: 1-25

Dill, R. F. (1964). Contemporary submarine erosion in Scripps Submarine Canyon. Ph.D. thesis, University of California, San Diego

Fauchald, K., Jumars, P. A. (1979). The diet of worms: a study of polychaete feeding guilds. Oceanogr. mar. Biol. A. Rev. 17: $193-284$

Franz, D. R., Tanacredi, J. T. (1992). Secondary production of the amphipod Ampelisca abdita and its importance in the diet of juvenile winter flounder (Pleuronectes americanus) in Jamaica Bay, New York. Estuaries 15: 193-203

Fredette, T. J., Diaz, R. J., van Montfrans, J., Orth, R. J. (1990). Secondary production within a seagrass bed (Zostera marina and Ruppia maritima) in lower Chesapeake Bay. Estuaries 13: 431-440

George, R. Y., Higgins, R. P. (1979). Eutrophic hadal benthic community in the Puerto Rico Trench. Ambio Spec. Rep. 6: $51-58$

Grassle, J. F., Grassle, J. P. (1974). Opportunistic life histories and genetic systems in marine benthic polychaetes. J. mar. Res. 32: 253-284

Grassle, J. F., Grassle, J. P. (1994). Notes from the abyss: the effects of a patchy supply of organic material and larvae on soft-sediment benthic communities. In: Giller, P. S., Hildres, A. G., Raffaelli, D. G. (eds.) Aquatic ecology: scale, pattern and process. Blackwell Scientific Publications, Oxford

Grassle, J. F., Morse-Porteous, L. S. (1987). Macrofaunal colonization of disturbed deep-sea environments and the structure of deep-sea benthic communities. Deep Sea Res. 34: $1911-1950$

Greene, C. H., Weibe, P. H., Burczynski, J., Youngbluth, M. J. (1988). Acoustical detection of high-density demersal krill layers in the Submarine Canyons off Georges Bank. Sci- 
ence $241: 359-361$

Griggs, G. G., Carey, J. A. G., Kulm, L. D. (1969). Deep-sea sedimentation and sediment-fauna interaction in Cascadia Channel and on Cascadia Abyssal Plain. Deep Sea Res. 16: 157-170

Hakanson, J. L. (1987). The feeding condition of Calanus pacificus and other zooplankton in relation to phytoplankton pigments in the California Current. Limmol. Oceanogr. 32: $881-894$

Hamilton, A. L. (1969). On estimating annual production. Limnol. Oceanogr. 14: 771-782

Highsmith, R. C., Coyle, K. O. (1990). High productivity of northern Bering Sea benthic amphipods. Nature 344: $862-864$

Highsmith, R. C., Coyle, K. O. (1991). Amphipod life histories: community structure, impact of temperature on decoupled growth and maturation rates, productivity and P:B ratios. Am. Zool. 31. 861-873

Hynes, H. B. N., Coleman, M. J. (1968). A simple method of assessing the annual production of stream benthos. Limnol. Oceanogr. 13: 569-573

Inman, D. L., Nordstrom, C. E., Flick, R. E. (1976). Currents in submarine canyons: an air-sea-land interaction. A. Rev. Fluid Mechanics 8: 375-310

Josselyn, M. N., Cailliet, G. M., Niesen, T M., Cowen, R., Hurley, A. C., Connor, J., Hawes, S. (1983). Composition, export and faunal utilization of drift vegetation in the Salt River submarine canyon. Estuar. coast. Shelf Sci. 17: $447-465$

Lampitt, R. S. (1985). Evidence for the seasonal deposition of detritus to the deep-sea floor and its subsequent resuspension. Deep Sea Res. 32: 885-897

Lasker, R. (1975). Field criteria for survival of anchovy larvae: the relation between inshore chlorophyll maximum layers and successful. first feeding. Fish. Bull. 73: 453-462

Lutz, R. A., Shank, T M. Fornari, D. J., Lilley, M. D., Von Damm, K. L., Desbruyeres, D. (1994). Rapid growth at deep-sea vents. Nature 371: 663-664

McHugh, C. M., Ryan, W. B. F., Hecker, B. (1992). Contemporary sedimentary processes in the Monterey Canyon-fan system. Mar. Geol. 107: 35-50

Meador, J P., Present, $\Upsilon$ M. C. (1985). Orchomene limodes, new species, a scavenging amphipod from Scripps Canyon, California: species description and analysis of morphological variation. J. Crust. Biol. 5: 523-538

Menzies, R. J., Zaneveld, J. S., Pratt, R. M. (1967). Transported turtle grass as a source of organic enrichment of abyssal sediments off North Carolina. Deep Sea Res. 14: $111-112$

Moller, P., Rosenberg, R. (1983). Recruitment, abundance and production of Mya arenaria and Cardium edule in marine shallow waters. Ophelia 22:33-55

Mullin, M. M. (1993). Webs and scales: physical and ecological processes in marine fish recruitment. Washington Sea Grant, Seattle

Mullin, M. M., Brooks, E. R. (1976). Some consequences of distributional heterogeneity of phytoplankton and zooplankton. Limnol. Oceanogr. 21: 784-796

Okey, T. A. (1993). Natural disturbances and benthic communities in Monterey Canyon Head. San Jose State University, Moss Landing, CA

Omori, M., Ikeda, T (1984). Methods in marine zooplankton ecology. John Wiley and Sons, New York

Pearson, T. H., Rosenberg, R. (1978). Macrobenthic succession in relation to organic enrichment and pollution of the marine environment. Oceanogr. mar. Biol. A. Rev. 16: $229-311$
Priede, I. G., Bagley, P. M., Armstrong, J D., Smith, K. L. Jr, Merrett, N. R. (1991). Direct measurement of active dispersal of food-falls by deep-sea demersal fishes. Nature $351 \quad 647-649$

Quast, J. C. (1971). Observations on the food of kelp bed fishes. The biology of giant kelp beds (Macrocystis) in California. Verlag J. Cramer, Lehre, p. 541-579

Rainer, S. F., Unsworth, P. (1991). Ecology and production of Nebalia sp. (Crustacea: Leptostraca) in a shallow-water seagrass community. Aust. J mar Freshwat. Res. 42: $53-68$

Rice, A. L., Lambshead, P. J. D. (1994). Patch dynamıcs in the deep-sea benthos: the role of a heterogeneous supply of organic matter. In: Giller, P. S., Hildres, A. G., Raffaelli, D. G. (eds.) Aquatic ecology: scale, pattern and process Blackwell Scientific Publications, Oxford

Ritz, D. A., Lewis, M. E., Shen, M. (1989). Response to organic enrichment of infaunal macrobenthic communities under salmonid seacages. Mar. Biol. 103: 211-214

Rogers, A. D. (1994). The biology of seamounts. Adv. mar. Biol. 30: 304-350

Rowe, G. T., Polloni, P., Haedrich, R. L. (1982). The deep-sea macrobenthos on the continental margin of the northwest Atlantic Ocean. Deep Sea Res. 21: 641-650

Rowe, G. T., Staresinic, N. (1979). Sources of organic matter to the deep sea. Ambio Spec. Rep. 6: 19-24

Shepard, F. P., Dill, R. F. (1966). Submarine canyons and other sea valleys. Rand McNally \& Co., Chicago

Smith, C. R. (1985). Food for the deep sea: utilization, dispersal, and flux of nekton falls at the Santa Catalina Basin floor. Deep Sea Res. 32: 417-442

Smith, C. R. (1987). Food energy supply and demand: a discrepancy between particulate organic carbon flux and sediment community oxygen consumption in the deep sea. Limnol. Oceanogr. 32: 201-220

Snelgrove, P. V R., Grassle, J F., Petrecca, R. F. (1992). The role of food patches in maintaining high deep-sea diversity: field experiments with hydrodynamically unbiased colonization trays. Limnol. Oceanogr. 37: 1543-1550

Steimle, F. W. (1987). Production by the benthic fauna, Georges Bank. Massachusetts Institute of Oceanography, Toppan Printing Co., Tokyo

Stockton, W. L., DeLaca, T E. (1982). Food falls in the deep sea: occurrence, quality and significance. Deep Sea Res 29: $157-169$

Suchanek, T. H. (1993). Oil impacts on manne invertebrate populations and communities. Am. Zool. 33: 510-523

Suchanek, T H., Williams, S. L., Ogden, J. C., Hubbard, D. K., Gill, I. P. (1985). Utilization of shallow-water seagrass detritus by Caribbean deep-sea macrofauna: $\delta^{13} \mathrm{C}$ evidence. Deep Sea Res. 32: 201-214

Thiel, H., Pfannkuche O., Schriever, G., Lochte, K., Hemleben, C. H., Mantoura, R. F. G., Turley, C. M., Patching, J. W., Riemann, F. (1988/1989). Phytodetritus on the deepsea floor in a central oceanic region of the Northeast Atlantic. Biol. Oceanogr. 6: 203-239

Unsworth, P. (1987). The ecology and production of the leptostracan, Nebalia nr longicornis Thomson. Murdoch University, Perth

VanBlaricom, G. R. (1982). Experimental analyses of structural regulation in a marine sand community exposed to oceanic swell. Ecol. Monogr. 52: 283-305

Vetter, E. W. (1994). Hotspots of benthic production. Nature 372: 47

Vetter, E. W (1995). Southern California Nebalia ecology, production, natural history and systematics or two subtidal species. Ph.D. thesis, University of California, San Diego 
Wildish, D. J. (1984). Secondary production of four sublittoral, soft-sediment amphipod populations in the Bay of Fundy. Can. J. Zool. 62: 1027-1033

Wildish, D. J., Wilson, A. J., Frost, B. (1989). Benthic macro-

This article was presented by N. D. Holland (Senior Editorial Advisor), La Jolla, California, USA faunal production of Browns Bank, Northwest Atlantic Can. J. Fish. Aquat. Sci. 46: 584-590

Wolff, T. (1976). Utilization of seagrass in the deep sea. Aquat. Bot. 2: 161-174

Manuscript first received: October 19, 1994

Revised version accepted: January 20, 1995 